ERRATUM I OPEN ACCESS

\title{
Erratum to: 'Normal endothelial but impaired arterial development in MAP-Kinase activated protein kinase 2 (MK2) deficient mice'
}

Vascular Cell 9:1 I DOI: 10.1186/s13221-016-0039-1 ～～ＣＬi et al.; licensee Publiverse Online S.R.L. 2016 Received: 11 Nov 2016 I Accepted: 15 Nov 2016 | Published: 23 Nov 2016

Napp L. Christian+ @ , Jabs Olga, Höckelmann Anna, Dutzmann Jochen, Kapopara Piyushkumar R., Sedding Daniel G., Gaestel Matthias, Bauersachs Johann, Bavendiek Udo

${ }^{+}$Contributed equally ${ }^{\circledR}$ Corresponding author

\section{Erratum}

Unfortunately, the original version of this article [1] contained an error. One of the author's names was incorrect. For the author Piyush R. Kapopara, the given name should have been published as Piyushkumar instead of Piyush. This is presented correctly in the above author list and will also be updated in the original article [ 1].

\section{Declarations}

The online version of the original article can be found under doi:10.1186/s13221-016-0038-2.

\section{Reference}

1. Napp LC Jabs O Höckelmann A Dutzmann J Kapopara PR Sedding DG Gaestel M Johann B Bauersachs J Bavendiek U Normal endothelial but impaired arterial development in MAP-Kinase activated protein kinase 2 (MK2) deficient mice Vascular Cell 201684 10.1186/s13221-016-003825073967 